\title{
REGIONAL APPROACHES TO INTERNATIONAL HUMANITARIAN LAW
}

\author{
Richard Burchill*
}

\begin{abstract}
Violations of international humanitarian law (IHL) are a global concern. The enforcement of IHL has traditionally focused on the State level. As States have shown an unwillingness or inability to address violations, attention has moved to the international level primarily through universal approaches such as the International Criminal Court. However, experience has demonstrated that universal approaches also have their limitations. This article argues that regional arrangements offer the possibility of strengthening the enforcement of IHL. As regional arrangements occupy a distinct space between particular local conditions and the universalising tendencies of the global system, they are well placed to handle the various concerns and considerations surrounding the enforcement of IHL.
\end{abstract}

\section{INTRODUCTION}

The creation of the International Criminal Court (ICC) is without doubt the most significant advancement to date in international efforts to ensure the effective enforcement of international humanitarian law (IHL). Prior to the creation of the ICC, efforts for addressing violations of IHL were inconsistently pursued through national criminal justice systems, and in more recent years through the creation of internationalised tribunals created to deal with particular events.

The ICC was set up to overcome the selective and essentially inconsistent past approaches and to ensure that impunity for violations of IHL no longer prevailed. The ICC aspires to these objectives through the creation of a permanent institution that is as independent as possible from political influence, and with a potentially universal reach over a particular set of offences that represent the most shocking violations of IHL. The universal potential of the ICC comes from the fact that every State in the world can conceivably become a State party, combined with the ability of the United Nations Security Council to refer cases that may involve a non-State party. The ICC was

* Director, McCoubrey Centre for International Law, Law School, University of Hull, United Kingdom. The author would like to thank Alberto Costi for the invitation to contribute to this issue and for the comments and advice provided on earlier drafts. 
erected to provide it with maximum independence and to ensure "the centrality of the role of law in international relations" in order to realise "the promise of a world in which the perpetrators of genocide, crimes against humanity and war crimes are prosecuted" as well as providing "the world a potential deterrent to future atrocities".

A great deal of hope has been attached to the ICC. In its eight years of existence, it has begun to show its utility. At the same time, recent events involving the ICC and the issuing of arrest warrants for the Sudanese President Omar Al-Bashir have shown the limitations of the ICC in pursuing its objectives. The Prosecutor of the ICC issued the warrants in 2009, which included an appeal process to expand the scope of the warrants, and this has resulted in a response from the African Union condemning the ICC. The ICC's actions regarding Bashir have been significant at a number of levels: it is the first referral from the Security Council, which occurred in 2005; and, it is the first time a serving Head of State has been charged by the ICC. ${ }^{2}$ It also brought to a head tensions developing between the ICC and the region of Africa, with the African Union taking a decision in early 2009 to petition the Security Council to suspend the case against Bashir. ${ }^{3}$ The African Union has expressed concern that only African States are on the ICC's docket (albeit there are three direct referrals from African States) and that the Prosecutor's pursuit of a serving Head of State in a conflict area undermines the local efforts for achieving a peaceful solution to the conflict. ${ }^{4}$ The African Union's position regarding the ICC is clearly based on a particular political agenda. At the same time, the decision to petition the Security Council was undertaken based on the legal provisions in the Rome Statute of the ICC (Rome Statute) enabling the Security Council to request a 12-month suspension of any investigation or prosecution. ${ }^{5}$ As the Security Council is itself a political body, albeit with legal obligations and responsibilities, the African Union's response to the ICC approach to the Security Council is part and parcel of international relations. Despite a strong desire to distance mechanisms designed to pursue justice following violations of IHL from politics, ${ }^{6}$

1 United Nations "There must be no relenting in fight against impunity, says Secretary-General as International Criminal Court Rome Statute comes into force" (press release, 1 July 2002) SG/SM/8293 $<$ www.un.org $>$.

2 Information on the actions of the International Criminal Court (ICC) regarding Omar Al-Bashir is available on the ICC website: <www.icc-cpi.int>.

3 Assembly of the African Union Decision on the Application by the International Criminal Court (ICC) Prosecutor for the Indictment of the President of the Republic of The Sudan AU Dec 221 Assembly/AU/Dec.221(XII) (2009) <www.africa-union.org $>$.

4 For an example of the position of the African Union, see African Union Communique on the 3 February 2010 Judgment of the International Criminal Court Appeals Chamber on Darfur (African Union, Addis Ababa, 2010) <www.africa-union.org $>$.

5 Rome Statute of the International Criminal Court (opened for signature 17 July 1998, entered into force 1 July 2002), art 16 [Rome Statute].

6 See M Cherif Bassiouni "From Versailles to Rwanda in Seventy-Five Years: The Need to Establish a Permanent International Criminal Court" (1997) 10 Harv Hum Rts J 11 at 13. 
this can never be fully achieved. The ICC has been designed to distance the institution from political manipulation, but equally it must function in an environment where a variety of political choices can be made and the pursuit of justice is just one of them. The African Union's actions were greeted with dismay; some commentators took the view that the African Union's decision to petition the Security Council demonstrated the threat posed to international law by regional arrangements. ${ }^{7}$

Concerns over the negative impact regional arrangements may have upon international law and relations have been a feature of the international system since the first attempts at creating universal international institutions. The nature of these concerns has not changed dramatically over time. They are grounded in the belief that regional approaches will deviate from the universal system, leading to fragmentation, weakening the system as a whole and potentially giving rise to conflict among different regional groups. While there is historical evidence that regional arrangements have contributed to conflict and may deviate from universal standards (however conceived), it is equally important to recognise that regional arrangements provide a number of practical and creative possibilities for furthering the overall objectives of the universal system. In discussions about the appropriate site of activity for international organisation, the regional and universal levels are often posed as exclusive choices to be made instead of taking a constructive approach in trying to manage action at both levels in a way that ensures the positive benefits of each approach are effectively harnessed in order to address issues of global concern.

The current system for the enforcement of IHL (understood here as the enforcement of those crimes for which individual criminal responsibility exists) focuses attention on the ICC at the universal level and national enforcement by states. Even though it is recognised that the ICC cannot, and will not, cover all aspects of IHL enforcement and that States have shown a reluctance to act upon their obligations in this area, the potential of regional arrangements contributing to international efforts for the enforcement of IHL remains "unexplored and underdeveloped". ${ }^{8}$ Greater attention to the regional level will support the enforcement of IHL through practical measures, such as ensuring the best use of resources, and by addressing normative concerns over legitimacy in dealing with IHL matters. There is no optimal formula for ensuring the effective enforcement of IHL, but as regional arrangements occupy a significant space between the global and the local, they offer a good deal of potential for supporting the effectiveness of IHL.

This article will first address in general terms the beneficial aspects that regional arrangements can provide in the pursuit of activities of common concern in the international system. The

7 See Wes Rist "SNAFU at the AU: Is Regionalism the ICC's Biggest Challenge?" (2009) Jurist Legal News and Research $<$ http://jurist.law.pitt.edu $>$.

8 See William Burke-White "Regionalization of International Criminal Law Enforcement: A Preliminary Exploration" (2003) 38 Tex Int'l LJ 729; R Burchill "Dealing with International Crime at the Regional Level" in Neil Boister and Alberto Costi (eds) Regionalising International Criminal Law in the Pacific (New Zealand Association for Comparative Law, Wellington, 2006) 31. 
discussion will then turn to how the legal relationship between the universal and regional has evolved in international law. It will draw upon the two preceding parts to examine how regional arrangements are able to contribute to a more effective system of IHL. This article strives to demonstrate that regional arrangements are not a threat to universal aspirations and that a more positive view needs to be taken of regional approaches as they provide both practical and normative benefits to the ongoing effectiveness of IHL and its enforcement.

\section{THE REGIONAL LEVEL OF INTERNATIONAL ORGANISATION}

By proposing that greater attention be given to the regional level in the enforcement of IHL, we must first make a case as to why such an avenue needs to be explored. IHL consists of an extensive legal regime built around both custom and treaties and there has been extensive academic commentary on the nature of obligations contained within this law. However, when it comes to dealing with violations of IHL, the effective enforcement of transgressions is something the international system has struggled to address. Antonio Cassese has provided a telling statistic: up to 1994 the criminal provisions of the four Geneva Conventions had not been applied by any domestic court. ${ }^{9}$ The ideal response to this would be that it was due to a lack of violations, but as Theodor Meron comments, it has been the failure of effective enforcement at the national level which has made greater international intervention necessary. ${ }^{10}$ While there have been significant international developments to address violations of IHL, these remain patchy as they are limited to specific conflict situations and, as will be discussed further below, the ICC will only address the most serious violations of IHL. ${ }^{11}$ The limitations of the international efforts so far, combined with the unwillingness of States to act, and the nature of conflicts in the world today result in the existence of substantial gaps in the effective enforcement of IHL. ${ }^{12}$ It is thus imperative to explore a variety of

9 A Cassese "Reflections on International Criminal Justice" (1998) 61 MLR 1 at 6.

10 Theodor Meron The Humanization of International Law (Martinus Nijhoff, Leiden, 2006) at 92.

11 Without wishing to downplay the significance of international efforts to address violations of international humanitarian law (IHL), the institutional arrangements created in the post-World War II period number only eight. For the limitations of the ICC, see below at notes 67-71 and the discussion provided by Mariacarmen Colitti "Geographical and Jurisdictional Reach of ICC: Gaps in the International Criminal Justice System and the Role for Internationalized Bodies" in C Romano, A Nollkaemper and J Kleffner (eds) Internationalized Criminal Courts: Sierra Leone, East Timor, Kosovo and Cambodia (Cambridge University Press, Cambridge, 2004) 417 at 426.

12 Conflicts today are primarily internal or on a limited scale involving immediate neighbours. These sorts of conflicts may or may not raise enough international interest to bring about direct action, but violations of IHL may have occurred which States alone will be unwilling to address. The latest example is Sri Lanka, which has rejected reports from the United Nations High Commissioner on Human Rights calling for an investigation into events that occurred in the final months of that country's civil war: see Jonathan Cohen "Sri Lanka president rejects proposed UN rights panel" (2010) Jurist Legal News and Research $<$ http://jurist.law.pitt.edu $>$. There is also the issue of breakaway territories, that is, territorial entities that do not recognise the authority of a particular State, but have not yet achieved statehood. In these situations, 
possibilities that will enhance effectiveness, and regional arrangements provide a number of positive features in this respect.

Regional arrangements are a central feature of the international system today as States and societies come together to address issues of common concern; yet, they have not been given a high degree of attention. ${ }^{13}$ International law in particular has yet to fully engage with the regional level of analysis despite the prominence of State behaviour that is carried out on a regional basis. ${ }^{14}$ For the discussion here, the "regional" level of analysis is the space between the universal global system and the State level. Regional arrangements are understood as a limited grouping of three or more States that have some geographical association and have formally come together in order to collectively pursue activities of common concern. Regional arrangements can be constituted through detailed legal agreements or through political agreements that are of an international nature, designed to commit the signatories to specific courses of action. ${ }^{15}$ The geographical connection will never be precise as definitions and perceptions about where geographical regions begin or end are subject to infinite debate. ${ }^{16}$ Therefore, in looking at specific examples of regional arrangements for the purposes of international law, it is necessary to focus on those groupings of States that have formally agreed to act in a collective fashion in order to avoid interminable debate as to whether a regional grouping may or may not exist. ${ }^{17}$

The regional level of analysis is an important space for enquiry in the current international system as it is proving to be integral to organisational responses in the wider processes of

armed conflict is a major feature, but the issue of jurisdiction and the inevitable politicization of any trials that may occur will not bode well for the effective enforcement of IHL.

13 PC Schmitter "Ancient Method, Novel Subject, Ambiguous Outcome" in A Ribeiro Hoffmann and A van der Vleuten (eds) Closing or Widening the Gap? Legitimacy and Democracy in Regional Integration Organizations (Ashgate, Aldershot (United Kingdom), 2007) xi at xi; International Law Commission Report of the Study Group on Fragmentation of International Law: Difficulties arising from the Diversification and Expansion of International Law A/CN.4/L.676 (2005) at [10].

14 For a useful discussion of how international law has dealt with competing claims to its universal nature, see A-C Martineau "The Rhetoric of Fragmentation: Fear and Faith in International Law" (2009) 22 LJIL 1.

15 An example of the former is the European Union, which has an extensive legal framework. An example of the latter is the Organisation for Security and Cooperation in Europe, which has political agreements with legal impact.

16 One only needs to compare the regional arrangements in Europe, such as the Council of Europe, the European Union and the Organisation for Security and Cooperation in Europe, which all claim to represent Europe, with drastically different memberships covering different geographical spaces.

17 This does not discount the importance of dealing with definitions of what constitutes a region or regional arrangement: see Rick Fawn "'Regions' and Their Study: Wherefrom, What for and Whereto?" (2009) 35 Review of International Studies 5 at 10-15. 
globalisation. ${ }^{18}$ This is due to the fact that action at the regional level occupies a unique space between the "discreteness of the State and the undifferentiated international system". ${ }^{19}$ In the world today, we are witnessing strong assertions of more localised identity in the face of the homogenising influences (either real or perceived) of globalisation. ${ }^{20}$ Regional arrangements are able to mediate this process by providing space for assertions of a particular communal identity within the overall international system. The assertion of communal identities in the international system is not per se an issue of fragmentation or deviance; rather, it is an expression of the reality inherent in the global system. ${ }^{21}$ Too often, discussions about regional approaches to international organisation are caught up in a fundamentalist approach to universalism which overlooks "the reality of pluralistic tendencies" in the international system. ${ }^{22}$ The recognition of diversity which exists in the world is critical, but at the same time, care must be taken not to overstate the situation leading to nihilistic relativism denying any existence of universally applicable values or norms. There is a delicate balance to be negotiated depending upon the particular circumstances faced. In the field of IHL, the universal nature and purpose of the system is undeniable, but at the same time, international practice has shown that effective implementation of IHL has not been forthcoming despite efforts at the universal and national levels, making it necessary to explore other possibilities.

The benefits of international organisational activities at the regional level are varied and diverse and it would be difficult to claim that any one regional arrangement exhibits all of the positive benefits discussed here. Concurrently, there are a number of features about regional arrangements that offer a positive contribution to international law and relations. The common history, traditions, social and cultural characteristics that States and societies may possess help foster more cooperative attitudes and facilitate agreement within a regional framework. The sense of solidarity that may exist due to a common outlook and geographical closeness will bring about the support and political

18 Mario Telò "Introduction: Globalization, New Regionalism and the Role of the European Union" in M Telò (ed) European Union and New Regionalism: Regional Actors and Global Governance in a Post-Hegemonic Era (2nd ed, Ashgate, Aldershot (United Kingdom), 2007) 1 at 5. See generally Fawn, above n 17, who includes a useful overview on the study of regions in international relations and substantial references.

19 LC Cantori and SL Spiegel "The Analysis of Regional International Politics: The Integration versus the Empirical Systems Approach" (1973) 27 Int'l Org 465 at 467; H Bull The Anarchical Society: A Study of Order in World Politics (MacMillan, London, 1977) at 305.

20 This has been described as a "central paradox of the world today": see David Forsythe and Patrice McMahon "Rights, Practices, and 'Area Studies'" in D Forsythe and P McMahon (eds) Human Rights and Diversity: Area Studies Revisited (University of Nebraska Press, Lincoln (Nebraska), 2003) 297 at 297.

21 See Yasuaki Onuma "A Transcivilizational Perspective on Global Legal Order in the Twenty-First Century: A Way to Overcome West-centric and Judiciary-centric Deficits in International Legal Thoughts" in R St John Macdonald and Douglas M Johnston (eds) Towards World Constitutionalism: Issues in the Legal Ordering of the World Community (Martinus Nijhoff, Leiden, 2005) 151.

22 VS Mani "Centrifugal and Centripetal Tendencies in the International System: Some Reflections" in St John Macdonald and Johnston, above n 21, 252. 
will necessary for collective action. The geographical space involved with most regional arrangements allows for a more efficient allocation of resources and brings about economies of scale when dealing with matters of common concern. These factors all contribute to the ability of regional arrangements to reach agreement on, and further the development of, international law in a number of subject areas. In particular, areas of sensitivity, such as human rights and potentially IHL, have seen developments at the regional level which have not been possible through universal arrangements. $^{23}$

Regional arrangements have been useful for the development of legal relations between States as they are able to foster a greater degree of legitimacy in the pursuit of international activities leading to enhanced compliance. ${ }^{24}$ The creation of legal and institutional frameworks at the regional level cannot be characterised as unwarranted or illegitimate interference as the States involved directly participate in their creation. When dealing with matters of common concern, regional arrangements will tend to have a better understanding of the circumstances involved as well as a better measure of the priorities which may be at stake in the pursuit of appropriate solutions. This also contributes to alleviating concerns about unwarranted interferences as the regional arrangement's involvement will likely be based on the concerns and needs of the immediate region. ${ }^{25}$ The permanent nature and potential expansion of institutional mechanisms among regional arrangements provide that they are better placed to ensure a lasting commitment to issues and problems facing the region. They are also able to ensure a degree of consistency and continuity in dealing with matters of importance to the region. ${ }^{26}$ The involvement of the regional arrangement will also imbue a greater sense of concern and belonging among States and societies as the range of priorities, concerns and extenuating factors to consider is much less in comparison to what a universal arrangement would have to deal with.

23 A clear example comes with the creation of international legal obligations concerning democratic governance. Agreement on a matter of this nature is likely to be impossible at the universal level, but the Council of Europe, the European Union and the Organization of American States have all implemented membership obligations, monitoring mechanisms and suspension procedures regarding democracy.

24 The European Union is the most obvious example of this phenomenon as it has created an extensive legal framework that supersedes domestic constitutional systems. For a broad survey, see K Lenaerts and P van Nuffel Constitutional Law of the European Union (2nd ed, Sweet \& Maxwell, London, 2005) at ch 17.

25 The involvement of the Association of Southeast Asian Nations (ASEAN) in the Cambodia-Vietnam conflict demonstrates the utility of regional awareness: see Yuen-Foong Khong and Helen Nesadurai "Hanging together, institutional design, and cooperation in Southeast Asia: AFTA and ARF" in A Acharya and AI Johnston (eds) Crafting Cooperation: Regional International Institutions in Comparative Perspective (Cambridge University Press, Cambridge, 2007) 32 at 42-44. In the context of human rights, see J Donnelly "International Human Rights: A Regime Analysis" (1986) 40 Int'1 Org 599 at 637.

26 While the United Nations does attempt to have a protracted presence in conflict areas, this often involves varying institutions of the universal body. Competing priorities along with financial costs mean that any presence is not necessarily permanent. 
Of course, these positive factors are far from absolute as the sort of closeness that is characteristic of regional arrangements does not exist in many parts of the world. Where closeness actually breeds conflict instead of cooperation among neighbours, it is unlikely a regional arrangement will be created. ${ }^{27}$ However, where regional arrangements have been created, there is still the potential for animosity among the members or manipulation from regional powers. ${ }^{28} \mathrm{Such}$ occurrences would diminish any bonds of solidarity and lead States to prefer action through universal arrangements. ${ }^{29}$ Regarding resources, it must be kept in mind that in some regions the institutional arrangements may not possess or have access to the necessary resources and knowledge that would be available with a universal body, preventing the regional institutions from making a constructive and effective contribution to the desires and objectives of the region. ${ }^{30}$

Although there are negative issues to consider in discussing regional arrangements, these are not insurmountable. Where regional arrangements have been created, they have demonstrated an ability to generate and further normative and institutional frameworks that have not been possible at the global level. The success of the European Union in ensuring peaceful relations among its members and creating a common economic union of such magnitude has been well documented. ${ }^{31}$ In the field of human rights protection, regional arrangements have shown a propensity for higher levels of agreement in more diverse areas alongside the creation of enforcement mechanisms than has been possible at the global level. ${ }^{32}$ This has occurred despite the fact that in the early years of the United Nations, especially as regards its efforts to establish an international system for the promotion and protection of human rights, there was hostility to suggestions about regional approaches on the basis

27 This has been the case in much of Asia, but the South Asian Association for Regional Cooperation (SAARC) has brought India and Pakistan together in a regional arrangement, albeit a limited one.

28 The actions of the United States in the context of the Organization of American States are a clear example: see TJ Farer The Grand Strategy of the United States in Latin America (Transaction, New Brunswick (New Jersey), 1988). Despite this, the Organization of American States was also able to further aspects of a normative agenda pertaining to human rights and democracy: see D Forsythe "Human Rights, The United States, and The Organization of American States" (1991) 13 Hum Rts Q 66 at 75-89.

29 See Christoph Schreuer "Regionalism v. Universalism" (1995) 6 EJIL 477 at 479.

30 This is a particular issue for the Pacific and the Pacific Islands Forum: see Charles Chauvel "Regionalism in the Pacific: Legal Implications for Regionalism" in Kennedy Graham (ed) Models of Regional Governance for the Pacific: Sovereignty and the Future Architecture of Regionalism (Canterbury University Press, Christchurch, 2008) 10.

31 The literature on the European Union is immense. For a useful overview of the positive benefits achieved through regional integration, see Walter van Gerven The European Union: A Polity of States and Peoples (Hart Publishing, Oxford, 2005).

32 See Richard Burchill "Regional Arrangements and the UN Legal Order" in Nigel White and Richard Collins (eds) International Organisations and the Idea of Autonomy (Routledge, London, 2010) at ch 17. For an overview of the contribution of regional arrangements to the promotion and protection of human rights, see Dinah Shelton Regional Protection of Human Rights (Oxford University Press, Oxford, 2008). 
that they would undermine global efforts based on universalism. ${ }^{33}$ Over time, however, it has been shown that both regional and universal approaches are compatible and the widespread coverage which has resulted strengthens the global system as a whole. ${ }^{34}$ The lessons learned from international human rights law are important for pursuing regional developments in IHL as the practical and normative issues involved are closely connected. ${ }^{35}$ International human rights law has demonstrated how regional arrangements, despite concerns over diversity, have provided both practical and normative benefits in furthering universal desires and objectives. This should come as no surprise as international law is a system that attempts to bring together diverse social and cultural systems. The desire for universalism has to recognise the extensive diversity that exists in the world. Ronald Yalem has observed that when action is taken through the United Nations: ${ }^{36}$

... the universality of the human spirit congeals. But in the practical application of universally supported principles is encountered the greatest difficulty in translating the unification of concerns into the responses of reality.

In overcoming the difficulties of realising the universal aspirations and desires of the international system, regional arrangements provide a great deal of possibility, provided that the regional and universal levels of action can be appropriately managed.

\section{THE LEGAL DIMENSIONS OF REGIONAL AND UNIVERSAL APPROACHES TO INTERNATIONAL ORGANISATION}

One of the difficulties in advocating a regional approach to any area of international legal activity is that there is no definitive organisational framework between the universal and the regional levels. The foundations of international law are based on the universal application of a common set of rules, principles and procedures. Adherence to this foundational understanding leads to tension when particular approaches to international behaviour are advocated since there is no means for organising the varying views that exist. ${ }^{37}$ In the creation of international institutional arrangements, there has been constant movement between regional and universal approaches, giving

33 K Vasak The International Dimensions of Human Rights (Greenwood, Westport (Connecticut), 1982) at 451.

34 See the wide ranging examples provided in High-level Panel on Threats, Challenges and Change $A$ More Secure World: Our Shared Responsibility (United Nations Department of Public Information, New York, 2004); World Commission on the Social Dimension of Globalization A Fair Globalization: Creating Opportunities for All (International Labour Organization, Geneva, 2004). See also Louise Fawcett "The Evolving Architecture of Regionalization" in M Pugh and WPS Sidhu (eds) The United Nations and Regional Security: Europe and Beyond (Lynne Rienner, Boulder, 2003) 11 at 12.

35 See generally Richard Burchill "International Criminal Tribunals at the Regional Level: Lessons from International Human Rights Law" (2007) 4 NZYIL 25.

36 R Yalem Regionalism and World Order (Public Affairs Press, Washington (DC), 1965) at 140.

37 Onuma, above n 21, at 151. 
rise to controversy over which approach is preferable. Recent history has shown a tendency toward favouring universal approaches when there appears to be fragmentation in the system or threats from distinct blocs. However, in response to universal experiments, States tend to gravitate towards regional approaches. ${ }^{38}$ Such vacillation has characterised the 20th century from the League of Nations to the United Nations, resulting in a lack of clarity regarding the relations and interactions between activities at the two levels.

The great universal projects of the League of Nations (League) and the United Nations were grounded in the belief that if all States and actors were part of the same institutional arrangement, and subject to the same legal obligations and responsibilities, then peaceful cooperation would result. This thinking was at the heart of plans for the League as Woodrow Wilson viewed the presence of regional alliances as one of the major contributing factors to World War I, bolstering his belief in the necessity of a single institutional system with a universal legal framework. ${ }^{39}$ At the same time, Wilson's aspirations for a universal system were tempered by the political realities of what States were actually doing in the pursuit of their international affairs, which included the existence of regional arrangements and pacts. The League Covenant attempted to include both visions by recognising that the Covenant would not "affect the validity of international engagements, such as treaties of arbitration or regional understandings", but equally that these agreements had to be in line with the objectives and purposes of the League project. ${ }^{40}$ Far from an adequate determination of the relationship between the League and regional arrangements, the Covenant did set out a basic principle of consistency which remains important today in managing the interactions and relations between regional and universal approaches.

The failure of the League is well known, with one of the contributing factors being its inability to secure a consistent global membership in order to realise the objective of universality. This factor is prominent in Carr's assessment of the League project, which he felt highlighted how the appeal of universalism struggled with the practical realities of international politics. Carr recognised that universal approaches to international organisation "may be a necessary convenience and valuable symbol", but that the League project was more about "theoretical and ineffective universalism" that ran contrary to the "practical and workable efforts of regionalism". ${ }^{41}$ Carr's assessment thus brings to light the view that universal projects will be popular for their symbolic value and the idealism inherent in their pursuit, but equally other organisational projects of a more limited scale will be pursued as required, given that any "universal" project will be limited in what it can achieve.

38 Inis L Claude Swords into Ploughshares: The Problems and Progress of International Organization (4th ed, Random House, New York, 1988) at 109. See also Martineau, above n 14.

39 Yalem, above n 36, at 39.

40 Covenant of the League of Nations, arts 20-21.

41 EH Carr Nationalism and After (Macmillan, London, 1945) at 45. 
Wilson's fears of regional arrangements as a threat towards universal aspirations persisted into the creation of the United Nations. ${ }^{42}$ At the same time, the drafting process for the United Nations Charter (Charter) saw greater and more realistic considerations of how regional arrangements were to fit with the universal project. The United States and the Soviet Union desired a universal organisation set up for the maintenance of international peace and security. Such organisation enabled them to become involved in conflicts around the world, as demonstrated by the creation of the Security Council and the authority that body was granted. At the same time, neither of the superpowers was willing to concede that the United Nations would be able to act within their respective spheres of influence or that they would need United Nations approval to pursue their own regional interests. ${ }^{43}$ The States of Latin America and the Middle East were at this time pursuing the creation of regional institutional arrangements and did not wish to see these efforts being subsumed by the universal organisation. ${ }^{44}$ These factors led to limited recognition of how regional arrangements would be connected to the United Nations project. Despite claims that the Charter has effectively addressed this relationship, ${ }^{45}$ it does not provide clear guidance on how the universal and regional approaches are connected beyond the limited field of peace and security. ${ }^{46}$

In relation to the maintenance of international peace and security, considerable coverage of the role of regional arrangements is provided in Chapter VIII of the Charter. These articles set out that the Charter does not preclude the existence of regional arrangements for dealing with matters of peace and security where it is "appropriate for regional action, provided that such arrangements or agencies and their activities are consistent with the Purposes and Principles of the United Nations". ${ }^{47}$ Both States and the Security Council are to make every effort to utilise regional arrangements for resolving disputes. Chapter VIII attempts to maintain the primacy of the United Nations system by requiring that any activity undertaken by a regional arrangement dealing with peace and security matters is to be reported to the Security Council. ${ }^{48}$ Other relevant provisions of the Charter include Article 51, which permits individual and collective self-defence activities

42 Claude, above n 38, at 106. A member of the United States negotiating team, Leo Pasvolsky, described regional arrangements as "reprehensible 'spheres of influence"': quoted in S Schlesinger Act of Creation: The Founding of the United Nations. A Story of Superpowers, Secret Agents, Wartime Allies and Enemies, and Their Quest for a Peaceful World (Westview Press, Boulder, 2003) at 176.

43 Schlesinger, above $\mathrm{n} 42$, at 36-44 and 183-185.

44 W Hummer and M Schweitzer "Article 52" in B Simma (ed) The Charter of the United Nations: A Commentary (2nd ed, Oxford University Press, Oxford, 2002) 807 at 814-817.

45 See the statements from Arthur Vandenberg, a member of the United States negotiating team, quoted in E Haas "The Challenge of Regionalism" (1958) 12 Int'l Org 238.

46 Hummer and Schweitzer, above n 44, at 814; Claude, above n 38, at 105-106.

47 Charter of the United Nations, art 52(1).

48 Ibid, art 54 
without Security Council authorisation - which regional arrangements have relied upon for action. Moreover, Article 103 of the Charter states that the legal obligations under the Charter will prevail over any conflicting obligations a member State may have entered into, which would include agreements for the creation of regional arrangements. Article 103 has been called a "supremacy clause", which gives the impression it creates a clear hierarchy between the universal and regional. ${ }^{49}$ At the same time, the wording of Article 103 is limited in its scope as it does not abrogate other international agreements. It rather only requires that conflicting obligations be harmonised to ensure consistency with the Charter. Furthermore, it applies only to the clearly defined legal obligations emanating from the Charter, which differs from the wording of Article 52, the latter referring to regional arrangements acting in a manner consistent with the purposes and principles of the Charter. ${ }^{50}$

The Charter framework's attention on regional arrangements is specific to action taken for addressing matters of international peace and security, even though there is a tendency to view these provisions as indicative of the position in general international law. The maintenance of international peace and security is one of the few clearly defined areas of legal obligations upon the member States, such as when the Security Council requires action under Chapter VII. However, even in this area, there has been an absence of effort to manage the relations between the regional arrangements and the United Nations in a constructive and cooperative fashion, making it difficult to draw any conclusions on legal practice in this respect. ${ }^{51}$

The end of the Cold War brought about a great deal of change in the international system, including a change in perspective regarding regional arrangements. In the 1992 document, An Agenda for Peace, the then United Nations Secretary-General Bhutros Bhutros-Ghali set out a number of important observations regarding regional arrangements. He explained that new thinking was needed in the international system with regard to how regional arrangements were viewed and that it was necessary to recognise the contributions they could make. ${ }^{52} \mathrm{He}$ further explained: ${ }^{53}$

Regional action as a matter of decentralization, delegation and cooperation with United Nations efforts could not only lighten the burden of the [Security] Council but also contribute to a deeper sense of participation, consensus and democratization in international affairs.

49 R Liivoja "The Scope of the Supremacy Clause of the United Nations Charter" (2008) 57 ICLQ 583 at 584.

50 See Hummer and Schweitzer, above n 44, at 825-826.

51 For an extensive discussion on the legal practice under art 52, see ibid, at 807-853.

52 Boutros Boutros-Ghali An Agenda for Peace, Preventative Diplomacy, Peacemaking and Peace-keeping: Report of the Secretary-General Pursuant to the Statement Adopted by the Summit Meeting of the Security Council on 31 January 1992 at [65], A/47/277 (1992).

53 Ibid, at [64]. 
Bhutros-Ghali's view set out two important components regarding the role of regional arrangements in the international system. First, he recognised that as a practical matter the United Nations alone cannot deal with every issue facing the world, even within the limited mandate of preserving and protecting international peace and security. Therefore, other actors and institutions need to be included in sharing the burden and regional arrangements are well placed to make a contribution. Secondly, he explained how regional arrangements provide a greater sense of belonging within the international system. The normative implications of this latter point are crucial where too often the appeal to universalism is equated with uniformity, which in turn fosters resistance from those who do not identify with the mainstream. This resistance is not a denial of universal aspects of the international system, but rather a desire to ensure that diverse views and voices are expressed and recognised. ${ }^{54}$

Further recognition of the practical and normative contribution of regional arrangements results from the 2004 Report of the High Level Panel on Threats and Challenges, where it was recognised that regional arrangements had "gone farther" than the United Nations in aspects of normative standards and prevention efforts. ${ }^{55}$ The Report also made a bold suggestion that the United Nations "should build on the experience of regional organizations" in certain areas as part of its own efforts in ensuring international peace and security. ${ }^{56}$

Despite the recognition that regional arrangements have a positive contribution to make, the latter continue to be marginalised in understandings of international law. ${ }^{57}$ As international law is historically a European creation, the idea of geographically bound entities with their own characteristics and identity is essentially an original feature of the international system. At the same time, European international law was based upon what were perceived to be universal ideas that were projected globally. ${ }^{58}$ Therefore, it is not wholly surprising that the activities of non-European or western regional arrangements are seen as threatening to, or deviating from, the universal aspirations of international law. However, while international law strives for universality, it also operates in a diverse world system. This diversity is recognised to a degree through the fundamental

54 For example, see Antony Anghie and BS Chimni "Third World Approaches to International Law and Individual Responsibility in Internal Conflict" in Steven Ratner and Anne-Marie Slaughter (eds) The Methods of International Law (American Society of International Law, Washington (DC), 2004) 185; Karin Mickelson "Rhetoric and Rage: Third World Voices in International Legal Discourse" (1998) 16 Wisconsin Int'l LJ 353.

55 High-Level Panel on Threats, Challenges and Change, above n 34, at [94].

56 Ibid.

57 International Law Commission Fragmentation of International Law: Difficulties Arising From The Diversification And Expansion of International Law at [195]-[196], A/CN.4/L.682 (2006). See also Mani, above $\mathrm{n} 22$, at 252 .

58 See Martti Koskenniemi The Gentle Civilizer of Nations: The Rise and Fall of International Law 1870-1960 (Cambridge University Press, Cambridge, 2001) at ch 2. 
principle of the sovereign equality of States. Nevertheless, difficulty may arise when a collection of States comes together for the purposes of pursuing issues of common concern which in turn result in the expression of a collective identity as well as the creation of institutional structures for action. The diversity of States is a social fact that is dealt with by appealing to the universal applicability of international law: the understanding that all States are required to adhere to their international obligations. However, in the absence of a single system of rule making or structures of governance, legal obligations evolve from a variety of sources and this is where regional arrangements are a cause of concern. When a grouping of States agrees upon international legal obligations applicable to their distinct grouping, as well as creates institutional mechanisms for oversight, the potential for fragmentation becomes acute. Concerns are then raised about competing obligations, the potential for forum shopping and contestations over finality regarding the source of a final authoritative judgment on the nature of the legal obligations in question. ${ }^{59}$

These are all matters that are particularly sensitive in IHL where the norms involved have a clear universal nature to them, but divergence exists regarding what measures constitute effective enforcement - which is one of the reasons for the creation of the ICC. Therefore, the idea that regional arrangements become involved in the enforcement of IHL may be interpreted as a threat to the coherence and capability of the universal ICC. This need not be the case. Instead of beginning with the negative view of regional arrangements as some form of deviance, it is necessary to view regional arrangements as efforts within and for the purposes of supporting the ongoing development of the international system. To do this, we need to first keep in mind Inis Claude's observations that any discussion about regional or universal approaches should not be about making a definitive choice between exclusive positions. Rather, it is a process to be managed and this: ${ }^{60}$

... requires an intelligent evaluation of the merits and demerits of the opposing tendencies which has not been notably present in the management of the shifting balance between regional and universal approaches to international organization.

We can then add to this a legal understanding put forth by Hersch Lauterpacht, where he explained that international law is: ${ }^{61}$

... in principle, of a general and universal character; it is intended to operate in relation to all its subjects. ... However, within the orbit of its general and universal operation it leaves room for

59 For a general discussion of these issues in international law, see Yuval Shany The Competing Jurisdictions of International Courts and Tribunals (Oxford University Press, Oxford, 2004) especially 8-11. In relation to tribunals dealing with IHL, see Markus Benzing and Morten Bergsmo "Some Tentative Remarks on the Relationship between Internationalized Criminal Jurisdictions and the International Criminal Court" in Romano, Nollkaemper and Kleffner, above n 11, 402 at 410-411.

60 Claude, above n 38, at 109.

61 E Lauterpacht (ed) International Law: Being the Collected Papers of Hersch Lauterpacht (Cambridge University Press, Cambridge, 1970) vol 1 at 112. 
adaptation, variation and detailed regulation ... between individual states or groups of states; it leaves

room for particular international law.

He then went on to say that the international law formulated at the regional level, "so long as it does not assume the complexion of a denial of the wider and universal international law, fulfils a useful function". ${ }^{6}$ For examples of the "useful function", he speaks of filling in the gaps of a developing universal international legal system as well as giving expression to "regional characteristics and traditions" as an indication of the diversity which exists in the world. ${ }^{63}$ Lauterpacht's view of regional arrangements is a positive one recognising the practical and normative contributions they make in support of international law. His only condition is that particular expressions from the regional level could not constitute a denial of general international law. Such an approach allows for diversity. In fact, it could be seen as promoting diversity, without threatening the overall system.

The perspective both Claude and Lauterpacht provide is recognition of the fact that the universal and regional levels of action can be accommodated in a single system based on constructive cooperation through mutual reinforcement of both practical and normative contributions. This sort of understanding has significant implications for, as Yasuaki Onuma has explained, the ongoing effectiveness of international law requires recognition and accommodation of the diversity that exists in the world. ${ }^{64}$ Equally, as Robert Jennings has succinctly put it, "[u]niversality does not mean uniformity" in international law. ${ }^{65}$

\section{REGIONAL APPROACHES TO INTERNATIONAL HUMANITARIAN LAW}

Suggesting a regional approach to the enforcement of IHL as part of the international system does potentially raise a number of concerns as it may be interpreted as suggesting IHL is subject to varying interpretations which would undermine its universality. This is emphatically rejected. The body of principles and rules which make up IHL is universal and is not being questioned. ${ }^{66}$ The purpose here is to suggest that greater attention to the regional level for addressing violations of IHL has the potential to support the system as a whole through a better use of resources, by expanding the coverage of institutional arrangements to address violations and enhancing critical normative

62 Ibid, at $112-113$

63 Ibid, at 113.

64 Yasuaki Onuma "When was the Law of International Society Born? - An Inquiry of the History of International Law from an Intercivilizational Perspective" (2000) 2 J Hist Int'1 L 1 at 65-66.

65 Robert Jennings "Universal International Law in a Multicultural World" in M Bos and I Brownlie (eds) Liber Amicorum for the Rt Hon Lord Wilberforce (Oxford University Press, Oxford, 1987) 41 at 41-42.

66 This is confirmed by the widespread ratification of the Geneva Conventions and Additional Protocols. See also Legality of the Threat or Use of Nuclear Weapons (Advisory Opinion) [1996] ICJ Rep 226 at [79]. 
aspects regarding the perceptions of legitimacy in undertaking enforcement measures. The Geneva Conventions make clear that State parties have treaty obligations to take action against individuals suspected of violations of the Conventions. ${ }^{67}$ States are also authorised under customary international law to exercise jurisdiction over other suspected violations of IHL. ${ }^{68}$ Despite the extensive nature of both the obligatory and permissive provisions for dealing with violations of IHL, the failures in the system regarding enforcement are well known. ${ }^{69}$ There have been significant developments with States expanding national jurisdictions to deal with IHL violations, but there also appears to be a recent trend to scale back the reach of domestic laws in this area in order to avoid political controversy. ${ }^{70}$ The lack of individual State action has been the impetus for international efforts to address violations of IHL in particular circumstances through the creation by the Security Council of international tribunals such as the International Criminal Tribunals for the former Yugoslavia and Rwanda or through "internationalised" tribunals that have been constructed through a combination of domestic and international elements. ${ }^{71}$ These efforts have been innovative in their

67 See Convention (I) for the Amelioration of the Condition of the Wounded and Sick in Armed Forces in the Field (opened for signature 12 August 1949, entered into force 21 October 1950), arts 49-54; Convention (II) for the Amelioration of the Condition of Wounded, Sick and Shipwrecked Members of Armed Forces at Sea (opened for signature 12 August 1949, entered into force 21 October 1950), arts 50-53; Convention (III) relative to the Treatment of Prisoners of War (opened for signature 12 August 1949, entered into force 21 October 1950), arts 129-132; Convention (IV) relative to the Protection of Civilian Persons in Time of War (opened for signature 12 August 1949, entered into force 21 October 1950), arts 146-159; Protocol Additional to the Geneva Conventions of 12 August 1949, and relating to the Protection of Victims of International Armed Conflicts (Protocol I) (opened for signature 8 June 1977, entered into force 7 December 1978), arts 85-91.

68 According to the study of the International Committee of the Red Cross (ICRC) on customary international humanitarian law, States have the right to exercise universal jurisdiction over war crimes, the duty to investigate war crimes committed on their territory or by their armed forces or nationals and the duty to cooperate with others in the investigation and prosecution of war crimes. These rights and duties are applicable to both international and non-international armed conflict: see J-M Henckaerts and L DoswaldBeck (eds) Customary International Humanitarian Law (Cambridge University Press and ICRC, Cambridge, 2005) vol 1 rules 157, 159, 161.

69 See Cassese, above n 9, at 6; Meron, above n 10, at 92.

70 See Jonathan Cohen "UK PM seeks to limit war crimes arrest warrants for international leaders" (2010) Jurist Legal News and Research $<$ http://jurist.law.pitt.edu $>$, reporting that the governments of France, Spain and the United Kingdom are all seeking to limit the ability of the exercise of universal jurisdiction. There is also the judgment of the International Court of Justice in Case Concerning the Arrest Warrant of 11 April 2000 (Democratic Republic of Congo v Belgium) (Judgment) [2002] ICJ Rep 3, which appears to have scaled back the ability of States to exercise jurisdiction over non-nationals with government status in relation to violations of IHL. At the very least the International Court of Justice's decision demonstrated a lack of clear understanding and agreement on the enforcement of IHL. For a discussion, see N Boister "The ICJ in the Belgian Arrest Warrant Case: Arresting the Development of International Criminal Law" (2002) 7 Journal of Conflict and Security Law 293.

71 The International Criminal Tribunal for Rwada was formally established pursuant to Resolution on the Establishment of an International Tribunal and Adoption of the Statute of the Tribunal SC Res 955, 
construction; equally, they have a limited existence and only relate to particular circumstances. With individual States being reluctant to act, and given the practical and political limitations to international efforts, it is imperative that other possible approaches to the enforcement of IHL are considered. $^{72}$

The primary shortcoming in institutional coverage for the enforcement of IHL is the unwillingness of States to act and the ad hoc nature of international responses. The ICC has been created to help alleviate these shortcomings, but gaps in coverage remain. The Rome Statute clearly states that the institution was created to deal with the most "serious crimes of concern to the international community as a whole", which means the ICC will only deal with the most high profile cases. ${ }^{73}$ The ICC's jurisdictional reach is limited to the core crimes of genocide, crimes against humanity, war crimes and now the crime of aggression. Within these defined crimes there exist various procedural limitations and the ICC has to be selective in the situations it pursues. ${ }^{74}$ The ICC's jurisdictional reach for the above defined crimes has the potential to be widely spread as it covers the territory and nationals, regardless of the territory they may be in, of the State parties. There are currently 111 State parties to the Rome Statute, which is a substantial number, but it also means there are still about 80 States that have not ratified the Statute. To help fill this gap, the Security Council does possess the ability to request the Prosecutor to investigate a matter through a Chapter VII reference. ${ }^{75}$ This matter is a rare occurrence and it is unlikely that following on from the Bashir situation the Security Council will exercise this authority again in the near future.

S/RES/955 (1994). The International Criminal Tribunal for the former Yugoslavia was formally established pursuant to Resolution Establishing the International Criminal Tribunal for the Former Yugoslavia SC Res 827, S/RES/827 (1993). For a study of internationalised tribunals, see Romano, Nollkaemper and Kleffner, above n 11; Alberto Costi "Hybrid Tribunals as a Viable Transitional Justice Mechanism to Combat Impunity in Post-conflict Situations" (2006) 22 NZULR 213.

72 For further elaboration on the following points and examples, see Burke-White, above $\mathrm{n} 8$, and Benzing and Bergsmo, above n 59, at 408-411. See also Robert Cryer and others An Introduction to International Criminal Law and Procedure (Cambridge University Press, Cambridge, 2007) at ch 2.

73 See Alain Pellet "Internationalized Courts, Better than Nothing ..." in Romano, Nollkaemper and Kleffner, above n 11, 437 at 438, who believes that only crimes which "deeply shock the conscience of humanity" justify an internationalised prosecution.

74 The procedural limitations in the Rome Statute, above $\mathrm{n} 5$, include art 124, which allows a State party to exclude the jurisdiction of the ICC regarding art 8 (war crimes) for a period of seven years following ratification. The recent agreement to include the crime of aggression provides that the ICC's jurisdiction will not be operational until 2017 and only after another vote by State parties: see ICC Press Release "Review Conference on the Rome Statute Concludes in Kampala" (12 June 2010) available at <www.icc-cpi.int $>$. The main issue of the limitations upon the ICC is that it will have to remain selective about the situations over which it exercises jurisdiction, limiting its activities to the most high profile cases: see F Pocar "The Proliferation of International Courts and Tribunals: A Necessity in the Current International Community" (2004) 2 JICJ 304 at 308; ND White The United Nations System: Toward International Justice (Lynne Rienner, Boulder, 2002) at 212-213.

75 Rome Statute, above n 5, art 13(b) 
Furthermore, as the Security Council is a political body, it cannot be expected to act in a consistent manner and certainly would never call for a reference regarding any of the permanent five members or their close allies, regardless of the circumstances involved. ${ }^{76}$ These shortcomings are not criticisms of the ICC as an institution, but merely a reflection of the limitations universal arrangements face due to the difficulties and realities involved in achieving agreement on the scope of activities. The ICC is significant for the symbolic value it embodies and it will, hopefully, over time have a greater impact, but this is not the only possibility for effectively addressing the enforcement of IHL.

The proximity of regional arrangements to events involving violations of IHL will help to ensure timely action is taken and to lower the costs involved in bringing perpetrators to justice. Regional arrangements will assist in limiting the distance travelled for investigations, evidence gathering and the conduct of trials, all of which contribute to efficiency savings and a better use of resources. ${ }^{77}$ Regional arrangements will be better placed to make full and effective use of local knowledge and expertise for pursuing investigations and prosecutions, a factor that is also crucial for fostering a closer connection to the communities and individuals that have been impacted by events. ${ }^{78}$ Also, by conducting trials through a regional forum that is physically closer to the events, witnesses and victims will be able to participate more effectively throughout the proceedings. ${ }^{79}$

Regional arrangements also provide another advantage in that they are institutional creations and not ad hoc features. The permanent presence will contribute to a more holistic approach to the enforcement of IHL. Responses that have so far come from the universal level have attempted to engage with the various stages of a conflict, but the disjuncture between the varying institutional bodies and personnel involved has been identified as a problematic issue. ${ }^{80}$ Action at the regional level will help to overcome the problems of disjuncture as regional arrangements are able to offer a higher degree of consistency in dealing with conflict situations, with similar or overlapping competences existing at the conflict prevention stage, into the immediate oversight of any conflict

76 Members of the Security Council unwilling to sign up to the Rome Statute are not hesitant about using the ICC in relation to events where they may have a vested interest. Russia has been active in submitting communications to the ICC regarding events in Georgia: see Report of the International Criminal Court to the United Nations for 2008/09 at [48], A/64/356 (2009).

77 This holds even for regional arrangements, such as the Pacific Islands Forum, that cover substantial geographical space. While some regions present difficulties in travel, these problems are more easily managed than having a tribunal outside the region.

78 Burke-White, above $\mathrm{n} 8$, at 734-735.

79 The Rome Statute provides that the ICC can sit elsewhere, which allows it to be closer to events. Commentators vary on the likelihood of this occurring: compare Benzing and Bergsmo, above n 59, at 409 with Burke-White, above $\mathrm{n} 8$, at 751 .

80 Bassiouni, above n 6, at 12 . 
situation, and then into carrying out investigations and trials if necessary. ${ }^{81}$ Furthermore, as reconciliation processes are integral aspects of any post-conflict situation and are better undertaken by those with some connection to the societies involved, ${ }^{82}$ regional arrangements will be much better placed than a universal institution to engage in these processes. The permanent presence and proximity of regional arrangements will further support holistic approaches to IHL through education and training that will instil a greater emphasis on preventative measures which is of equal, if not greater importance. ${ }^{83}$ This will include assisting the development of national jurisdictions for ensuring the enforcement of IHL, something that contributes to the objectives of the ICC. For example, regional arrangements can support networks of national authorities dealing with IHL and international criminal justice issues. The example of the European Union's European Competition Network, which brings together the regulatory authorities from all the member States to discuss law and policy, is a model worth exploring to ensure consistency and the effective sharing of information on both substance and procedure. ${ }^{84}$ This is an area where regional arrangements can directly contribute to the objectives of the ICC and help share the workload, not least since there is a good deal of work to be done in bringing the legal systems of national jurisdictions in line with their obligations under the Rome Statute. ${ }^{85}$

The creation of institutional arrangements to address violations of IHL at the regional level will raise concerns about jurisdictional overlaps, possible conflicting interpretations of the law and issues of finality with judgments. ${ }^{86}$ While there can be no doubt that an increase of institutions will lead to

81 This is not guaranteed as multiple regional arrangements may equally create confusion and disjuncture between the stages of a conflict. Much will depend on how the actions of multiple actors are interpreted. See the useful study provided in Jan Wouters and Frederik Naert "How Effective is the European Security Architecture? Lesson from Bosnia and Kosovo" (2001) 50 ICLQ 540.

82 For a discussion on the importance of understanding localised cultural views, see Jessica Almqvist "The Impact of Cultural Diversity on International Criminal Proceedings" (2006) 4 JICJ 745.

83 H McCoubrey International Humanitarian Law (2nd ed, Ashgate, Aldershot (United Kingdom), 1998) at 279. See also David Turns "Implementation and Compliance" in E Wilmshurst and S Breau (eds) Perspectives on the ICRC Study on Customary International Humanitarian Law (Cambridge University Press, Cambridge, 2007) 354.

84 On the work of the European Competition Network, see European Competition Network "Overview" $<$ http://ec.europa.eu>.

85 There is some concern that States which have signed and ratified the Rome Statute have not correspondingly drawn up the necessary domestic legislation: see Roy Lee "State Responses: Issues and Solutions" in Roy Lee (ed) States' Responses to Issues Arising from the ICC Statute: Constitutional, Sovereignty, Judicial Cooperation, and Criminal Law (Transnational, Ardsley (New York), 2005) 1 at 1-2. In turn, this will have a substantial impact on the effectiveness of the ICC: see Hugo Relva "The Implementation of the Rome Statute in Latin American States" (2003) 16 LJIL 331 at 337-338.

86 For a general discussion of these issues in international law, see Shany, above $\mathrm{n}$ 59, at 8-11. In relation to tribunals dealing with IHL, see Benzing and Bergsmo, above n 59, at 410-411. 
complications, it is also a process that can be managed. ${ }^{87}$ As we move forward with the creation of further institutional arrangements, it is necessary to ensure they are mutually supportive, interactive and interdependent, rather than wholly separate entities existing without anything beyond a vague recognition of other similar bodies. ${ }^{88}$ This is what occurred in international human rights law, but given the nascent development of international institutional arrangements for dealing with violations of IHL, the opportunity exists to ensure activities are coordinated. There is evidence of greater interaction among existing international tribunals, which of course helps to support effective communication, the sharing of experiences, and contributes to greater consistency. ${ }^{89}$ These events have shown that there remains a divergence in opinion about the need to formalise relations and connections between tribunals. ${ }^{90}$ Simultaneously, with today's technology, the sharing of information and awareness of the experiences of others are not difficult tasks provided there is at least a willingness to engage and a commitment to a principle of consistency. ${ }^{91}$ A further option comes from the ICC, which has set up memoranda of understanding with existing internationalised courts for the purposes of cooperation and started to interact with the African Union in light of recent developments. ${ }^{92}$ Similar patterns involving treaty arrangements or memoranda of understanding can be used to construct formal foundations at a horizontal level, between regional institutions, and vertically, involving relevant regional and universal bodies. However, it has been

87 Pocar, above n 74, at 307.

88 See William Burke-White "A Community of Courts: Toward a System of International Criminal Law Enforcement" (2003) 24 Mich J Int'l L 1 at 75-76.

89 Examples include the five colloquia that have been held since 2004 between the prosecutors of the five international tribunals. The Brandeis University's International Center for Ethics, Justice and Public Life sponsors an Institute for International Judges and Judicial Colloquia events: see "A Forum for International Judges" <www.brandeis.edu>.

90 Brandeis Institute for International Judges "Complementarity and Cooperation: International Courts in a Diverse World" (2006) Brandeis University at 7-8<www.brandeis.edu $>$.

91 The Special Panel for Serious Crimes, the tribunal system created under the United Nations Transitional Administration in East Timor, demonstrated the limits to modern communication as the Special Panel's decisions were highly questionable under international law and created significant confusion. The matter was compounded by the lack of experienced international judges who were available to the Special Panel and the lack of support given to the domestic system by the United Nations: see generally Sylvia de Bertodano "East Timor: Trials and Tribulations" in Romano, Nollkaemper and Kleffner, above n 11, 79; Alison Ryan "The Special Panels for Serious Crimes of Timor-Leste: Lessons for the Region" in Boister and Costi, above n 8, 93; Richard Burchill "From East Timor to Timor-Leste: A Demonstration of the Limits of International Law in the Pursuit of Justice" in J Doria, H-P Gasser and C Bassiouni (eds) The Legal Regime of the International Criminal Court: Essays in Honour of Prof. Igor Blishchenko (Brill Publishing, The Hague, 2009) 255 at 279-281 ["From East Timor to Timor-Leste"].

92 There has been a memorandum of understanding in place between the ICC and the Special Court for Sierra Leone and there is talk of cooperation between the ICC and the Organisation of American States and the African Union: see Report of the International Criminal Court to the United Nations for 2008/09 at [63] and [70], A/64/356 (2009). 
suggested that institutional jealousies could become an obstacle to constructive cooperation if future institutions were created to deal with matters that overlap with the ICC. ${ }^{93}$

Institutional jealousies will be exacerbated by the absence of any clear organising hierarchy in international law. The proliferation of international institutions dealing with matters of common concern has not seen a parallel organising framework. In the absence of cooperation arrangements between institutions, each individual body is likely to confine itself to its own constitutive system. Scholars have identified a number of substantive issues arising from the proliferation of tribunals and which may lead to detrimental consequences. Scholars have identified a number of substantive issues arising from the proliferation of tribunals and which may lead to detrimental consequences. ${ }^{94}$ Commonly, arguments against proliferation point to how diverging views undermine the universal nature of international law, that different tribunals will incorrectly formulate understandings of the law, which in turn may be exploited by others in order to avoid conviction. ${ }^{95}$ These concerns are equally applicable when reliance is placed upon national jurisdictions to uphold international law. As William Burke-White explains, regional approaches may actually help to minimise inconsistencies and divergence because it would mean a limited number of tribunals as opposed to 192 different national jurisdictions. ${ }^{96}$ Ensuring consistency in the application of IHL relies upon fostering the political will and willingness to engage in a collective fashion that seeks to achieve "constructive cooperation" 97 for the overall purpose of upholding respect for IHL.

In the context of regional arrangements, the pursuit of constructive cooperation needs to overcome the fears and suspicions of fragmentation. The fears centre on the belief that regional institutions will interpret international law in a particular fashion that does not correspond to what is believed to be the prevailing universal perspective (however defined), thereby undermining the development of a coherent international legal framework. Suspicions are grounded in the belief that States will manipulate regional systems to justify their actions, which in turn would impede the effectiveness of international relations and potentially lead to conflict as regional groupings will attempt to impose their version of legal obligations upon others. More critically for the universalist position in international law, differing regional interpretations will impact the credibility of international law as its objectivity will be brought into question when standards are not applied uniformly across regions.

93 Cryer and others, above n 72, at 163.

94 A widespread study is provided by Jonathan Charney "Is International Law Threatened by Multiple International Tribunals?" (1998) 271 Recueil des Cours 101. Also, see generally (1999) 31(4) NYU J Int'l L $\& \mathrm{P}$ devoted to the proliferation of international courts and tribunals.

95 Burke-White, above n 8, at 756-757.

96 Ibid, at 758 note 185 .

97 Benzing and Bergsmo, above n 59, at 416. 
In the context of IHL, this is not only a matter of substantive jurisprudence, but also a question of timing regarding the pursuit of prosecutions. This is a particular issue for IHL since the enforcement of violations is too often caught up in the belief that there are tensions between the pursuit of justice and the quest for peace in conflict situations. The African Union's position on Bashir is based on this point and criticism of the African Union is directed at this very matter, based on the belief that the African Union is supporting impunity and looking to protect one of its own. However, the African Union has also cited Security Council practice and resolutions on the matter and, as already stated, its request that the Security Council delay proceedings before the ICC is well within the ICC's framework. The ICC system was created to distance the pursuit of justice as far as possible from political pressures that would influence the conduct of proceedings. Equally, the ICC does not and cannot exist in a vacuum where the pursuit of justice is the only concern, hence the inclusion of the Security Council's role in the ICC framework. We must also look at international practice in this regard as well for it reveals that despite the strong claims about the end of impunity and how the pursuit of justice cannot be conditioned by the "vagaries of realpolitik", the pursuit of justice is but one consideration in dealing with conflict situations. ${ }^{98}$

Two examples will suffice to highlight how the belief in a universal end to impunity is an aspiration, but equally one that has not been fully realised. The first comes from international efforts to deal with the conflict and post-conflict situation in East Timor. The Security Council authorised the creation of a hybrid tribunal to deal with the serious violations of IHL which occurred in 1999 in East Timor. ${ }^{99}$ In the course of events, there were continual exhortations from the Secretary-General of the United Nations and the Security Council calling for those responsible for violations of IHL to be brought to justice. ${ }^{100}$ But as the hybrid tribunal undertook its tasks, it became clear that the demands of justice had to compete with, and in some cases give way to, other considerations regarding the future of the territory. In the end, those most responsible for violations of IHL, members of the Indonesian military, were not brought to justice because Indonesia did not cooperate with the tribunal and the Security Council made no significant effort to ensure its compliance. ${ }^{101}$ The other example involves the response from the Prosecutor of the International Tribunal for the former Yugoslavia regarding the bombing actions of the North Atlantic Treaty Organization (NATO) in Yugoslavia during 1999. As with the situation in East Timor, there was widespread evidence of violations of IHL attributable to NATO forces; yet, the response from the Tribunal

98 Bassiouni, above $\mathrm{n} 6$, at 13

99 For details, see Report of the International Commission of Inquiry on East Timor A/54/726 and S/2000/59 (2000).

100 SC Res 1264, S/Res/1264 (1999) used the term "demands" that those responsible for the violence are brought to justice; yet, the Security Council never took any substantive action to ensure Indonesia complied.

101 For further discussion, see Burchill "From East Timor to Timor-Leste", above n 91. 
made clear that political considerations and not the pursuit of justice would prevail. ${ }^{102}$ These examples demonstrate that while there is universal condemnation for serious violations of IHL, bringing those responsible to justice is subject to wider considerations. Of course, the desire is to follow Bassiouni's guidance already mentioned above and try to ensure that attempts to address violations of IHL are safeguarded from the whims and unpredictability of "realpolitik". ${ }^{103}$ Equally, we must recognise the reality of international law and relations where justice cannot always be pursued independently of all other considerations. This does not necessarily mean that impunity prevails, only that it may be delayed or dealt with through other means. The African Union's response regarding the need for a delay in proceeding against Bashir is well in line with international practice provided it can be argued effectively that other considerations are as important to the pursuit of justice at this stage. The African Union has declared its commitment to removing impunity. It has not argued that no action should be taken for dealing with violations of IHL in Sudan, only that it would be better dealt with by those who are closer to the situation.

The difficulty we face with the African Union's position on dealing with Sudan is that fear and suspicion attached to non-western systems attempting to exert an independent position in international law. And it is for this very reason that regional arrangements will play such an important role in the ongoing development of international law. As already stated, regional arrangements occupy a unique space between the national and universal levels of action. On the one hand, they are creations within international law and as such provide the external international element for addressing issues of international concern. On the other hand, they are creations among a specific grouping of states and societies, thereby providing institutions made up of those from the region based on their shared beliefs and outlooks. This results in the creation of international institutions that exist with a degree of autonomy from States, yet not too far detached from the particular localised conditions of the societies in the region. A common refrain in opposition to international efforts for dealing with violations of IHL has been based on a belief in a lack of awareness of the local conditions, giving the impression that they are instruments of a sort of "victors' justice". ${ }^{104}$ This is an element that can be greatly minimised through regional arrangements as States and societies are more inclined to follow the directives of a regional arrangement since the supervisory bodies that exist are seen as more localised creations.

More importantly, regional arrangements will also foster a greater sense of localised ownership, which will help to enhance the legitimacy and acceptance of international law in the region. Regional arrangements are well placed to foster a "sound balance" between the general and the

102 See Anghie and Chimni, above n 54, at 199. The Prosecutor's response was that "no inquiry was useful and that nothing would emerge". In short, politics prevailed over any consideration of law and justice.

103 Bassiouni, above n 6, at 13 .

104 See Burke-White, above n 8, at 736-737. 
particular, seeming less intrusive when there is a need for external action or oversight. ${ }^{105}$ The internationalised or hybrid tribunals that have been created in the international system demonstrate that some combination of international and local mechanisms and participation are necessary to ensure legitimacy and effectiveness when dealing with violations of IHL. ${ }^{106}$ The experience to date has been mixed as there is evidence to show that both the international and the local element have been weaknesses in the overall operations of the tribunals. ${ }^{107}$ The basic principles behind these tribunals are informative in demonstrating the positive contribution of regional arrangements, for it is recognised that a universal body cannot stand at a distance and effectively pass judgment. The combination of the local and the international is a difficult process to get exactly right in a way that satisfies all those concerned and there will always exist in any grouping of States a belief from certain actors that an instrument or action is biased or that particular agendas are being imposed upon certain sections of society. ${ }^{108}$ However, in a situation where a limited number of States have agreed to the creation of a regional instrument to deal with specified violations of international law, accusations of bias or illegitimacy are much harder to sustain. In this respect, it would be a constructive move by the Security Council to delay the ICC proceedings regarding Bashir and turn the matter over to the African Union to deal with. Given the African Union's stated positions on the situation, this would not mean impunity or compromise would prevail. The Constitutive Act of the African Union rejects impunity as one of the principles of the organisation. ${ }^{109}$ The adoption of the African Charter on Human and Peoples Rights and the eventual creation of a human rights court further signify a stance against impunity. ${ }^{110}$ And in direct response to the Bashir situation there have been calls for the creation of an African Union mechanism to deal with the matter. ${ }^{111}$ This mechanism could not just decide that Bashir was somehow

105 Benzing and Bergsmo, above n 59, at 410.

106 See Ivan Šimonović "Dealing with the Legacy of Past War Crimes and Human Rights Abuses: Experiences and Trends" (2004) 2 JICJ 701.

107 See Costi, above n 71, at 236-238.

108 A useful study is provided by Ellen Emilie Stensrud "New Dilemmas in Transitional Justice: Lessons from the Mixed Courts in Sierra Leone and Cambodia" (2009) 46 Journal of Peace Research 5.

109 Constitutive Act of the African Union (opened for signature 11 July 2000, entered into force 26 May 2001), art $4(0)$.

110 See African Charter on Human and Peoples Rights (opened for signature 27 June 1981, entered into force 21 October 1986); Protocol to the African Charter on Human And Peoples' Rights on the Establishment of an African Court on Human And Peoples' Rights (opened for signature 9 June 1998, entered into force 1 January 2004).

111 The African Union has called for the creation of a hybrid court to deal with the Al-Bashir matter in order to maintain legitimacy and ensure international standards are met: see Andrea Bottorff "African Union calls for hybrid court to try Darfur genocide cases" (2010) Jurist Legal News and Research < jurist.law.pitt.edu>. The African Union has stated its rejection for impunity and belief in international law: see African Union Communiqué on the 3 February 2010 Judgment of the International Criminal Court Appeals Chamber on Darfur (African Union, Addis Ababa, 2010) available at <www.africa-union.org $>$. On the position of the 
immune from prosecution; it would have to act and investigate the matter, and the Security Council could keep the matter under review. If it became clear that the African Union was not willing to act, the Security Council could revoke the delay and then return the matter to the ICC if necessary. By turning the matter over to the African Union, it would not be an example of politics prevailing over justice, but rather an opportunity to make use of regional and universal levels of action and exploiting the beneficial aspects that each has to offer in order to reach a solution. By engaging the African Union in the enforcement of IHL, Sudan and other States in the region are more likely to engage with the process as arguments regarding the ICC impeding upon regional sensitivities and priorities could no longer be sustained.

More importantly, the involvement of the African Union and other regional arrangements in the enforcement of IHL will support the overall development by injecting a greater degree of diversity into the system. As Lauterpacht acknowledged, diversity is to be welcomed in the ongoing development of international law. Boutros-Ghali's call for greater participation by regional arrangements was equally based on a belief that diversity will help to enhance the system as a whole. In calling for greater diversity through regional arrangements, there does remain the condition that any expression of diversity does not constitute a complete denial of the applicable international law, a condition that equally applies to States. The involvement of regional arrangements in the enforcement of IHL would bring a greater degree of diversity that would strengthen approaches to the law by demonstrating the effectiveness of various methods for dealing with violations. ${ }^{112}$ Equally, it would provide a continual reaffirmation of the value and belief in IHL and international law more generally from a greater variety of sources. Recognition of diversity in approaches to IHL is inherent in the regimes established by custom, the Geneva Conventions and the ICC framework. In each case, action is first and foremost to be taken at the national level with no express uniform model put forth as to how enforcement action should occur. Diversity in dealing with criminal responsibility is a prominent feature at the national level and has impacted upon international efforts so far. Neither the ICC framework nor the Geneva Conventions provide for explicit recognition of other international tribunals, but there is also nothing precluding the existence of regional arrangements as "States can do jointly what they may do severally". ${ }^{113}$

The most important contribution regional arrangements can provide to the ongoing development of IHL is a greater sense of participation through the expression of identity across diverse groupings. If States and societies feel they are part of the overall system and that their particular

African Union, see also Peace and Security Council Press Statement AU Doc PSC/PR/BR(CXLI) (2009) $<$ www.africa-union.org $>$.

112 A commentator on regional developments in the area of security makes the general point that while much of our attention focuses on the European experience, "[t]he African, Latin American, and Asian experiences may offer insights Europe cannot": Fawcett, above n 34, at 11.

113 Meron, above n 10, at 118-119. 
circumstances and views are duly respected, then greater levels of participation in the processes of international law will follow. One of the more problematic aspects of any universal system is the belief that it insists upon uniform behaviour through the application of a uniform moral code. In the context of international law, this results in the marginalisation of views and perspective that do not correspond with the dominant ideology which is based around western and European views. ${ }^{114} \mathrm{We}$ can build upon the point made by Jennings with perspectives from cosmopolitanism in order to understand that a universal system does not require absolute uniformity in the way principles are pursued. ${ }^{115}$ There is no universal agreement as to how IHL is to be enforced and even within the ICC system individual States are putting forth their own, potentially conflicting, interpretations on enforcement. ${ }^{116}$ Even though there is strong rhetoric about the need for justice to prevail through the effective enforcement of IHL, there is no set formula and perspectives of what constitutes justice even in the wake of serious violations of IHL will vary. ${ }^{117}$ Those involved with international tribunals have recognised that it is not possible to apply supposed immutable truths; rather, there is a need to have a wider understanding of context when engaging in enforcement activities. ${ }^{118}$ Similarly, it has been argued that the true test of international efforts regarding IHL will be measured by the impact they have on the ground. ${ }^{119}$ Koskenniemi explains that our choices regarding appropriate institutions for international activity need to engage a process of debate involving real evidence and not the application of vague universal principles. ${ }^{120}$ All of these views

114 This does not explain completely the unwillingness of countries such as the United States, Russia and China to participate in the ICC framework. The position of these States is based purely on self-interested politics and no amount of talk will get them involved in the current institutional framework, due to the perceived impact on their sovereign position in the world.

115 Explained in the context of human rights, see Charles Jones Global Justice: Defending Cosmopolitanism (Oxford University Press, Oxford, 1999) at 174-175.

116 When Australia ratified the Rome Statute, it issued a declaration that Australian nationals may only be tried by the ICC if a warrant is issued by the Australian government and that any warrant only covers crimes implemented in accordance with Australian law: see Dominic McGoldrick "Political and Legal Responses to the ICC" in Dominic McGoldrick, Peter J Rowe and Eric Donnelly (eds) The Permanent International Criminal Court: Legal and Policy Issues (Hart Publishing, Oxford, 2004) 389 at 400. This results in Australia, and not the Prosecutor, determining when Australian nationals can appear before the ICC, a political, not a legal, position.

117 See the examples of the North Atlantic Treaty Organization and East Timor discussed above.

118 See Brandeis Institute for International Judges "Authority and Autonomy: Defining the Role of International and Regional Courts" (2003) Brandeis University at $7<$ www.brandeis.edu>. See also Almqvist, above n 82, at 751 .

119 See ICC Chief Prosecutor Luis Moreno Ocampo "Report of Proceedings (Colloquium of Prosecutors of International Criminal Tribunals Arusha 25-27 November 2004)" (2004) International Criminal Tribunal for Rwanda at $5<$ www.unictr.org $>$.

120 Koskenniemi, above n 58, at 178. Robert Cryer argues that comments in relation to this view regarding developments in international criminal law, the positive and negative benefits of international efforts to date, are becoming clearer: Robert Cryer "Sudan, Resolution 1593, and International Criminal Justice" 
point to the need to find effective mechanisms that link the reality of localised events with the aspirations of the universal system. The best way forward is through regional institutional arrangements that are situated between the local and universal and, if properly managed, the local, regional and universal can all make contributions to the process of international organisation. ${ }^{121}$

Increased attention to the regional level of activity will not only have the practical benefit of expanding institutional coverage for the enforcement of IHL to States and societies that are less than enthusiastic about developments at the universal level. It will also provide significant normative developments for international law by both requiring and providing enhanced understandings of the diversity which exists in the world by fostering cross-cultural perspectives on international activity. Regional arrangements can provide support for cross-cultural discussions regarding the enforcement of IHL as they will allow for diversity to be recognised while simultaneously maintaining the necessary degree of external perspective for ensuring universal norms are upheld. This does require recognition of the different ways of upholding and protecting universally applicable values, but in a way that does not bring the foundations into question. ${ }^{122}$ For Boaventura de Sousa Santos, universality is "an aspiration of completeness" and, in order to understand that the aspiration to universality and the diversity of actual practice are not mutually exclusive, there needs to be "discursive tolerance, readiness to incorporate alternative knowledges, preference for suppressed and marginalized knowledges". ${ }^{123}$ To incorporate these dimensions into discussions about the regional level, we return to Claude's view that the relationship between regional and universal is one that needs to be managed and not one based on mutually exclusive choices. This is central to developing cross-cultural perspectives. As An-Na'im explains, universal positions and diverse expressions "can be compatible and even mutually supportive, but this process should not be taken for granted or assumed to necessarily yield a predetermined or inevitable meaning and content of universality". ${ }^{124}$ He goes on to say that the universal view and culturally and contextually specific expressions can be mutually supportive or not; it depends on how actors view the process. In any case, the outcome has to be based on careful analysis and assessment of practical experience, "rather than assertions of categorical, nonnegotiable positions." 125 These positions all demonstrate that

(2006) 19 LJIL 195 at 203. The assertion here is that the evidence shows that neither a purely national nor an exclusively international framework is working as desired.

121 In the situation of Kosovo, the failure of the universal response to engage with the regional actors was detrimental to the situation: see David Marshall "Reviving the Judicial and Penal System in Kosovo" in Pugh and Sidhu, above n 34, 155 at 166-167.

122 Jones, above n 115, at 174-175.

123 Boaventura de Sousa Santos Toward a New Legal Common Sense (2nd ed, LexisNexis, London, 2002) at 269 and $272-274$

124 AA An-Na'im "'Area Expressions' and the Universality of Human Rights: Mediating a Contingent Relationship" in Forsythe and McMahon, above n 20, 1 at 1.

125 Ibid, at 1-2. 
focusing attention at the regional level is not automatically damaging for the universal aspirations of international law. Similarly, they underline the necessity of remaining acutely aware of the diversity which exists in the world and providing mechanisms for the expression of this diversity. Regional arrangements have established positions regarding IHL that will help to ensure that the universal and regional approaches are consistent and based on constructive cooperation whereby diversity is expressed, but within the universal framework. ${ }^{126}$

Ensuring the effective enforcement of IHL is an acute problem facing the international system as a whole. Violations of IHL shock the conscience of humankind, but at the same time the political will to address the problem is often lacking. ${ }^{127}$ The development of the ICC alongside the willingness of States to act in this regard has been significant in recent years, although serious gaps in effective enforcement remain. Action at the regional level will not close all the gaps and it will not guarantee all violations of IHL are dealt with. Equally, a staunch adherence to an exclusive universal approach is not going to solve these problems either. Greater attention to the possibilities and benefits offered by regional arrangements will go a long way in improving the current system by contributing to the institutional coverage and the better use of resources, combined with enhancing a greater sense of acceptability as enforcement measures from the regional level will have a greater degree of credibility and legitimacy. As Burke-White has explained, violations of IHL involve crimes of concern for the whole international community, but the "the peace and security implications of such crimes are often greatest within the region where the crimes occur". ${ }^{128}$ To ensure international law can best address the needs and desires of people on the ground, we have to recognise the diversity that exists in the world and accommodate the institutional arrangements that exist as part of this diversity.

\section{CONCLUSION}

Greater attention to regional arrangements will help to effectively foster a stronger global approach to international law. Regional arrangements demonstrate the diversity of the international system in a positive way. Instead of viewing regional arrangements as automatically deviant from the universal system, they must be seen as contributing to the universal aspirations of international law by supporting expressions of diversity. Speaking in the context of international human rights law, Richard Falk explains how: ${ }^{129}$

126 See the examples provided in Henckaerts and Doswald-Beck, above n 68, at 510 .

127 See Dinah Shelton "Introduction" in Dinah Shelton (ed) International Crimes, Peace and Human Rights: The Role of the International Criminal Court (Transnational, Ardsley (New York), 2000) ix. See also Patrick Zahnd "How the international criminal court should help implement international humanitarian law" in Shelton, 43 at 44.

128 Burke-White, above $\mathrm{n} 8$, at 733.

129 Richard Falk Human Rights Horizons: The Pursuit of Justice in a Globalizing World (Routledge, London, 2000) at 93. 
... the interplay of different cultural and religious traditions suggests the importance of multicivilizational dialogue involving the participation of various viewpoints ... . The world does not need a wholesale merging of different cultures and civilizations; rather it simply needs to foster a new level of respect and reconciliation between and among its ever changing and ever diverse peoples and nations.

The importance of recognising the diversity in the world has been highlighted as "an essential tool to conceive of any transboundary issues affecting nations and people, particularly issues relating to global validity and legitimacy". ${ }^{130}$ IHL is a global issue and violations of IHL are a global concern. At the same time, these violations occur in diverse societies where perspectives may vary. Judges on the ICC have called for greater diversity in the Court's framework in order to accommodate the varying perspectives that exist. ${ }^{131}$ The enforcement of IHL has traditionally focused on the State level. As States have shown an unwillingness or inability to address violations, attention has moved to the international level primarily through universal approaches. As experience is demonstrating, the universal approaches also have their limitations and it is clear that the enforcement of IHL needs to be addressed by effectively managing the benefits that accrue from engaging with all levels of international activity - the universal, the national and the regional.

130 Onuma, above n 21, at 171.

131 ICC Judge Kunilo Ozaki from Japan has reportedly called for more balanced regional representation on the Court: see Steve Czajkowski "Japan ICC judge urges more Asian participation to balance court" (2010) Jurist Legal News and Research <jurist.law.pitt.edu>. 
